\title{
Inventory and Assessment of Palaeontological Sites in the Sousa Basin (Paraíba, Brazil): Preliminary Study to Evaluate the Potential of the Area to Become a Geopark
}

\author{
Wellington Francisco Sá dos Santos ${ }^{1}$. Ismar de Souza Carvalho ${ }^{1}$. \\ Jose Bernardo Brilha ${ }^{2} \cdot$ Giuseppe Leonardi $^{3}$
}

Received: 9 November 2014 / Accepted: 11 November 2015 / Published online: 20 November 2015

(C) The European Association for Conservation of the Geological Heritage 2015

\begin{abstract}
The Rio do Peixe rift basin developed during the Lower Cretaceous (Neocomian) and comprises the Sousa, Uiraúna-Brejo das Freiras, Pombal and Vertentes basins. In these basins, there is an abundant ichnofauna mainly composed of theropod, sauropod and ornithopod dinosaur trackways that represent the palaeontological heritage of the region. As the majority of the fossiliferous areas are located in the Sousa basin, an inventory and assessment of the scientific, educational and touristic values, together with the vulnerability of 25 palaeontological sites, is here presented and discussed. The aims of the study are to guide the strategies of geoheritage protection in the Sousa basin and to evaluate the scientific potential of the area as a geopark. In general, the geosites of the Sousa basin have low scientific and touristic values, moderate educational value and high vulnerability. The fossiliferous areas are suffering from strong natural and anthropic threats and are at high risk of degradation. For these
\end{abstract}

Wellington Francisco Sá dos Santos

wfsasantos@gmail.com

Ismar de Souza Carvalho

ismar@geologia.ufrj.br

Jose Bernardo Brilha

jbrilha@dct.uminho.pt

Giuseppe Leonardi

gi.leonardi@libero.it

1 Departamento de Geologia, Universidade Federal do Rio de Janeiro, Centro de Ciências Matemáticas e da Natureza, Instituto de Geociências, Av. Athos da Silveira Ramos, 274. Bloco F. 21941-916, Cidade Universitária, Ilha do Fundão, Rio de Janeiro, RJ, Brazil

2 Earth Sciences Centre, University of Minho, Campus de Gualtar, 4710-057 Braga, Portugal

3 Istituto Cavanis, DD 898 Venezia, Italy reasons, based on the quality of the palaeontological sites, the region currently has little potential to become a geopark.

Keywords Sousa basin $\cdot$ Dinosaur tracks $\cdot$ Palaeontological heritage $\cdot$ Geoconservation strategies $\cdot$ Geopark

\section{Introduction}

The Rio do Peixe rift basin in NE Brazil comprises the Sousa, Uiraúna-Brejo das Freiras, Pombal and Vertentes basins. These basins originated in the Lower Cretaceous (Neocomian), along preexisting structural lineaments of the basement, during the opening of the Atlantic Ocean. The basins are located almost entirely in the western region of the Paraiba state, comprising a total area of $1250 \mathrm{~km}^{2}$.

In the Rio do Peixe basin, there is an abundant ichnofauna composed of theropod, sauropod and ornithopod dinosaur trackways. In addition, there are invertebrate trace fossils produced by arthropods and annelids, fossils of ostracods, conchostracans, plant fragments, palynomorphs, fish scales and crocodylomorph bone fragments (Moraes 1924; Leonardi 1979a, 1979b, 1987, 1989; Leonardi et al. 1987a, 1987b, 1987c; Godoy and Leonardi 1985; Lima and Coelho, 1987; Santos and Santos 1987a, 1987b; Carvalho 1989, 1993, 1996a, 1996b, 2000a, 2000b, 2004; Carvalho and Carvalho 1990; Carvalho et al. 2013a; Fernandes and Carvalho 1997; Leonardi and Santos 2004; Leonardi and Carvalho 2007). However, the majority of the sites are located in the Sousa basin where dinosaur tracks are the main aspect of the local geological heritage (Siqueira et al. 2011).

The sedimentary rocks of the Rio do Peixe basin belong to the Rio do Peixe Group, which comprises the Antenor Navarro, Sousa and Rio Piranhas formations (Fig. 1). During the Lower Cretaceous, the region had a warm climate, 


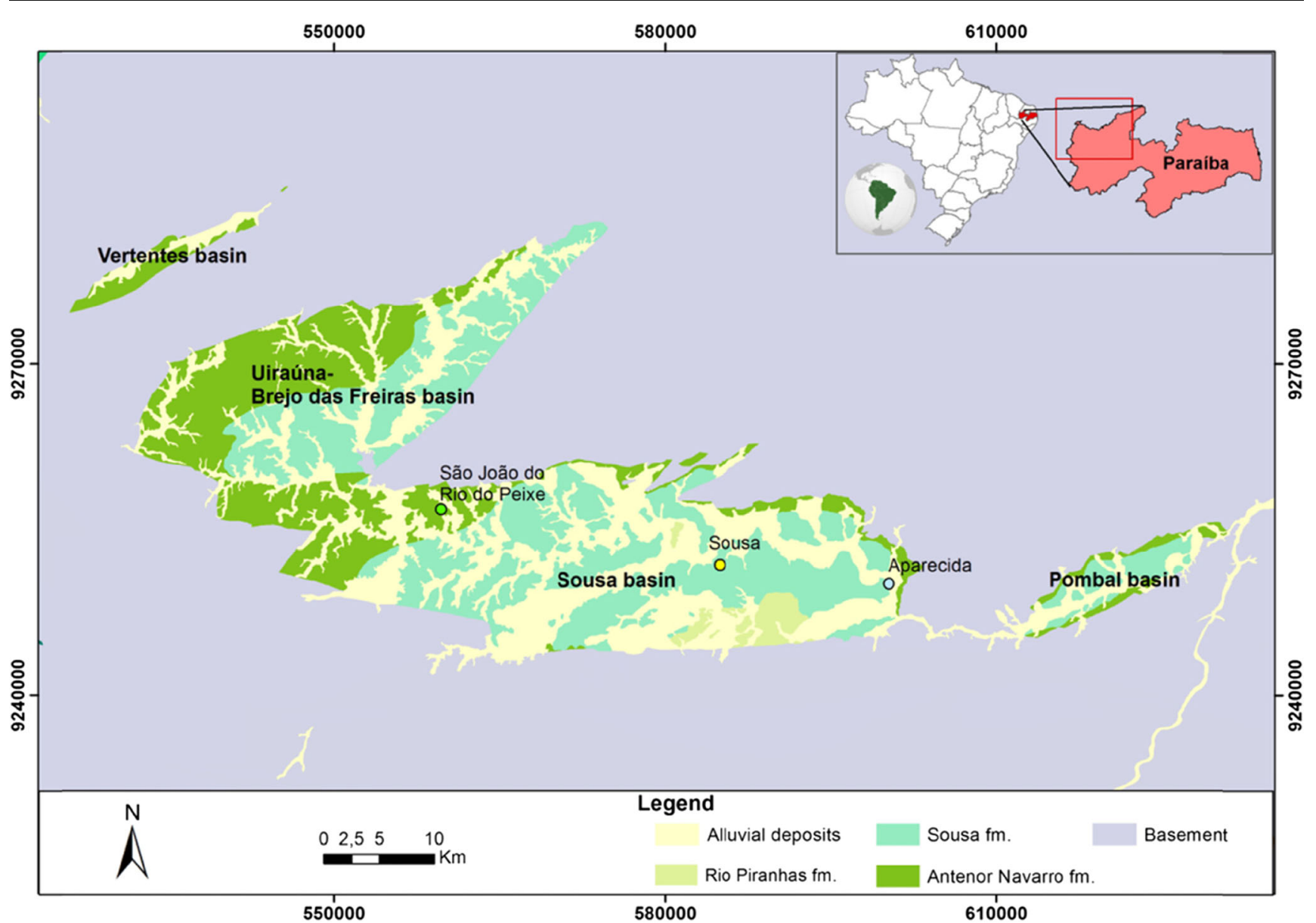

Fig. 1 Geological map of Rio do Peixe basin (including Sousa, Uiraúna-Brejo das Freiras, Pombal and Vertentes basins) with emphasis on the Rio do Peixe group. The Sousa, São João do Rio do Peixe and Aparecida municipalities are also represented (modified from CPRM-Geological Survey of Brazil, sheet Sousa SB.24-ZA)

The palaeontological sites of the Sousa basin not only are mostly within the Sousa municipality, but are also present in smaller number in São João do Rio do Peixe and Aparecida counties. A brief characterization of these administrative areas is presented in Table 1 -all have a medium human development index and low demographic density.

The inventory carried out in these three municipalities generated a list of 25 palaeontological sites. The most important locality in terms of the distribution of fossil footprints is known as Passagem das Pedras (in the municipality of Sousa). On 20 December 1992, this area was designated as
Table 1 Area, inhabitants, demographic density and Human Development Index (HDI) of Aparecida, Sousa and São João do Rio do Peixe municipalities

\begin{tabular}{lllll}
\multicolumn{6}{l}{ General characterization of Sousa, Aparecida and São João do Rio do Peixe municipalities } \\
\hline Municipalities & Area $\left(\mathrm{km}^{2}\right)$ & Inhabitants & Demographic density (inhabitants $\left./ \mathrm{km}^{2}\right)$ & HDI \\
\hline Aparecida & 229 & 5.894 & 25.73 & 0.628 \\
Sousa & 842 & 62.635 & 74.38 & 0.658 \\
São João do Rio do Peixe & 474 & 17.661 & 37.25 & 0.595 \\
\hline
\end{tabular}

Adapted from IBGE (2010a, 2010b) and PNUD (2000) 
Table 2 Criteria, indicators and numeric parameters to quantify the scientific, educational and touristic values, together with vulnerability of the Sousa basin palaeontological sites

Criteria, indicators and numeric parameters for assessing of the scientific, educational and touristic values and vulnerability of Sousa basin palaeontological sites

1. Representativeness (SVW=30; $\mathrm{EVW}=0$; TVW=0; VUW=0)

The geosite is the best known example in the study area

The geosite is a good example in the study area

The geosite is a reasonable example in the study area

2. Local-type character $(\mathrm{SVW}=20 ; \mathrm{EVW}=0$; $\mathrm{TVW}=0 ; \mathrm{VUW}=0$ )

Geosite used, of the scientific point of view, as an international reference

Geosite used, of the scientific point of view, as a national reference

Geosite used, of the scientific point of view, as a regional and/or local reference

3. Integrity $(\mathrm{SVW}=15 ; \mathrm{EVW}=0 ; \mathrm{TVW}=0$;

$\mathrm{VUW}=0$ )

Geosite well conserved and practically intact

Geosite with deterioration, but that does not affect, crucially, its geological features

Geosite with deterioration that does not allow the perception of some important geological features

4. Rarity $(\mathrm{SVW}=15 ; \mathrm{EVW}=0 ; \mathrm{TVW}=0$;

VUW=0)

The geosite is the only or one of few known examples at national level

The geosite is the only known example in the area under analysis

The geosite is one of the few examples known in the area under analysis

5. Scientific knowledge $(\mathrm{SVW}=10 ; \mathrm{EVW}=0$;

$\mathrm{TVW}=0 ; \mathrm{VUW}=0$ )

There are scientific publications of international character dedicated to geosite

(theses, papers, books, etc.).

There are scientific publications of national character dedicated to geosite or there are references to geosite in scientific publications of international character

There are references to geosite in scientific publications of national character

6. Geological diversity $(\mathrm{SVW}=10 ; \mathrm{EVW}=0$;

TVW=0; VUW=0)

Geosite with more than three geological interests with scientific value (mineralogical, palaeontological, geomorphological, sedimentological/stratigraphic, etc.)

Geosite with three geological interests with scientific value

Geosite with two geological interests with scientific value

7. Didactic potential $(\mathrm{SVW}=0 ; \mathrm{EVW}=20$; $\mathrm{TVW}=0$; VUW=0)

Illustrates products and geological processes

in a clear and expressive way for all levels of the educational system

Points

4

1

Points
Table 2 (continued)

Illustrates products and geological processes

in a clear and expressive

way to classes from elementary school onwards

Illustrates products and geological processes

in a clear and expressive

way to classes from high school onwards

Illustrates products and geological processes

in a clear and expressive way only for

higher education

8. Geodiversity elements $(\mathrm{SVW}=0 ; \mathrm{EVW}=15$;

TVW=5; VUW=0)

The geosite presents more than three types of geodiversity elements

(invertebrates fossils, bioturbations, dinosaur

footprints, ripple marks, mud cracks, etc.)

The geosite presents three types of geodiversity elements

The geosite presents two types of geodiversity elements

The geosite presents one type of geodiversity elements

9. Observing conditions $(\mathrm{SVW}=0 ; \mathrm{EVW}=15$;

TVW=5; VUW=0)

All geological contents are readily observable

in all seasons

There are obstacles that hinder the observation

of some geosite content at certain times of year

There are obstacles that hinder the observation

of the main geosite contents at certain times of year

There are obstacles that impede the observation

Points of the main geosite contents in all seasons

10. Vulnerability $(\mathrm{SVW}=0 ; \mathrm{EVW}=10 ; \mathrm{TVW}=10$;

VUW=0)

Without possibility of content deterioration

by anthropic activity (students or tourists)

Possibility of secondary content deterioration

by anthropic activity (students or tourists)

Possibility of main content deterioration by

anthropic activity (students or tourists)

Possibility of all content deterioration by

anthropic activity (students or tourists)

11. Accessibility $(\mathrm{SVW}=0 ; \mathrm{EVW}=10$;

TVW=10; VUW=0)

Geosite less than $100 \mathrm{~m}$ of a paved road and

with bus parking

Geosite less than $500 \mathrm{~m}$ of a paved road

Geosite only accessible by unpaved road,

but travelled by bus

Geosite without direct access by road,

Points but less than $1 \mathrm{~km}$ from a passable route

12. Safety $(\mathrm{SVW}=0 ; \mathrm{EVW}=10 ; \mathrm{TVW}=15$;

$\mathrm{VUW}=0$ )

Geosite with safety equipment (fences, walls, stairs, railings, etc.), mobile phone network coverage and less than $5 \mathrm{~km}$ of assistance means

Geosite with safety equipment (fences,

walls, stairs, railings, etc.), cellular network

coverage and less than $25 \mathrm{~km}$ of assistance means

Geosite without safety equipment,

Points

4

3

2

Points

4

3

2

Points

4

3

2

Points

4

3

2

Points

4

3

but with cellular network coverage

and less than $50 \mathrm{~km}$ of assistance means

Geosite without safety equipment, without cellular network coverage

and more than $50 \mathrm{~km}$ of assistance means 
Table 2 (continued)

13. Logistics infrastructure $(\mathrm{SVW}=0$

$\mathrm{EVW}=10 ; \mathrm{TVW}=5 ; \mathrm{VUW}=0$ )

Accommodation and restaurant for

groups of 50 people at less than $10 \mathrm{~km}$

Accommodation and restaurant for

groups of 50 people at less than $20 \mathrm{~km}$

Accommodation and restaurant for

groups of 50 people at less than $30 \mathrm{~km}$

Accommodation and restaurant for

groups of 50 people at less than $40 \mathrm{~km}$

14. Association with other values $(\mathrm{SVW}=0$;

$\mathrm{EVW}=5 ; \mathrm{TVW}=10 ; \mathrm{VUW}=0$ )

Presence of various ecological and cultural values in a radius of $5 \mathrm{~km}$

Presence of various ecological and cultural values in a radius of $10 \mathrm{~km}$

Presence of one ecological and one cultural value in a radius of $10 \mathrm{~km}$

Presence of a unique ecological or cultural

value in a radius of $10 \mathrm{~km}$

15 . Scenic beauty $(S V W=0 ; E V W=5$;

TVW=20; VUW=0)

Geosite habitually used in touristic

documentation at national level

Geosite occasionally used in touristic

documentation at national level

Geosite habitually used in the touristic

documentation at regional or local level

Geosite occasionally used in touristic

documentation at regional or local level

16. Outreach potential $(\mathrm{SVW}=0 ; \mathrm{EVW}=0$;

$\mathrm{TVW}=15 ; \mathrm{VUW}=0$ )

Illustrates products and geological processes

in a clear and expressive way

for the general public

Illustrates products and geological processes

in a clear and expressive way

to the public with some geological knowledge

Illustrates products and geological processes

in a clear and expressive way

to the public with solid geological knowledge

Illustrates products and geological processes

in a clear and expressive way

to the specialist public in geology

17. Proximity to recreational areas $(\mathrm{SVW}=0$;

$\mathrm{EVW}=0 ; \mathrm{TVW}=5 ; \mathrm{VUW}=0$ )

Geosite situated less than $5 \mathrm{~km}$ from

a recreational area

Geosite situated less than $10 \mathrm{~km}$ from

a recreational area

Geosite situated less than $15 \mathrm{~km}$ from

a recreational area

Geosite situated less than $20 \mathrm{~km}$ from

a recreational area

18. Deterioration by natural and

anthropic action $(\mathrm{SVW}=0 ; \mathrm{EVW}=0$;

TVW=0; VUW=35)

Possibility of all geological item

deterioration by anthropic and natural action

Possibility of main item deterioration by

anthropic and natural action

Possibility of secondary item deterioration

by anthropic and natural action
Table 2 (continued)

Without possibility of geological item

deterioration by anthropic and natural action

19 . Proximity to potentially degrading zones

$(\mathrm{SVW}=0 ; \mathrm{EVW}=0 ; \mathrm{TVW}=0 ; \mathrm{VUW}=25)$

Geosite located close to four or more potentially

Points degrading zones (residential areas/

2 human trampling, mining activities, river flooding, construction of dams, recreational areas,

1 rock fracturation, cattle treading, uncontrolled

growth of vegetation and proximity to railways).

Geosite located close to three potentially

degrading zones

Geosite located close to two potentially

2

degrading zones

Geosite located close to one potentially

1

degrading zone

2 20. Protection regime $(\mathrm{SVW}=0 ; \mathrm{EVW}=0$;

TVW=0; VUW=25)

Geosite situated in an area without protection

regime and none access control

Geosite situated in an area without protection

regime but with access control

Geosite situated in an area with protection

regime and none access control

Geosite situated in an area with protection

regime and access control

21. Accessibility for vulnerability analysis

$(\mathrm{SVW}=0 ; \mathrm{EVW}=0 ; \mathrm{TVW}=0 ; \mathrm{UVW}=15)$

Geosite at less than $100 \mathrm{~m}$ of paved road,

with parking for buses or outcropping on

a dirt road

Geosite at less than $100 \mathrm{~m}$ of paved road

Geosite at less than $100 \mathrm{~m}$ of road without

asphalt or geosite located between 100 and

$500 \mathrm{~m}$ of paved road

Geosite to more than $100 \mathrm{~m}$ of dirt road or over $500 \mathrm{~m}$ of paved road

Each criterion has a specific weight for the value and vulnerability: scientific value weight (SVW), educational value weight (EVW), touristic value weight (TVW) and vulnerability weight (VUW) (adapted from Brilha 2015)

the 'Dinosaur Valley Natural Monument' (Decree No.

14.833); however, geoconservation strategies for other geosites of the basin have not yet been carried out (Santos 2014). Scientific, educational and touristic values, together with a vulnerability index, were assessed for these 25 sites. This study contributes to the establishment of strategies to assure geoheritage protection in the Sousa basin.

The study area is included in a geopark project proposed by the Brazilian Geoparks Programme lead by CPRM, the Geological Survey of Brazil (Ferreira et al. 2014). A geopark, according to UNESCO (2014), is a territory with well-defined limits, which is large enough area to allow local economic development. The geopark should comprise a certain number of sites associated with geological heritage with a special scientific importance, rarity or beauty or be representative of an 
Table 3 Classification of scientific, educational and touristic values and vulnerability into four classes: very low, low, moderate and high

\begin{tabular}{ll}
\hline Range & Value and vulnerability \\
\hline $0-100$ & Very low \\
$101-200$ & Low \\
$201-300$ & Moderate \\
$301-400$ & High \\
\hline
\end{tabular}

Adapted from Brilha (2015)

area and its geological history, events or processes. In addition, a geopark should have ecological, archaeological, historical or cultural values. The current study carried out on the palaeontological heritage of the area is intended to contribute to this project by evaluating if the scientific relevance of the included fossil sites can justify such a project.

\section{Materials and Methods}

For the inventory and quantification of palaeontological sites in the Sousa basin, the method of Brilha (2015) was used with adaptations to the local situation. There is a specific method to quantify the values of dinosaur ichnite sites proposed by Mampel et al. (2009). However, the method of Brilha (2015) is the most current and a compilation of the best practices described in the literature, in association with the experience of the author, creates an integrated proposal for the quantitative assessment of all types of geosite and geodiversity site.

A detailed description and photographic record of potential geosites were completed in 2013 during fieldwork. The characterization of these potential geosites included their geographical coordinates, the municipality and geological formation in which the palaeontological elements occur, as well as the main features and threat, and information about what action is needed to protect the fossils. Subsequently, the palaeontological sites of Sousa basin were numerically assessed for their scientific, educational and touristic values, together with their vulnerability.

For the quantification process, 21 criteria were used, with numerical parameters ranging from 1 to 4 . The value

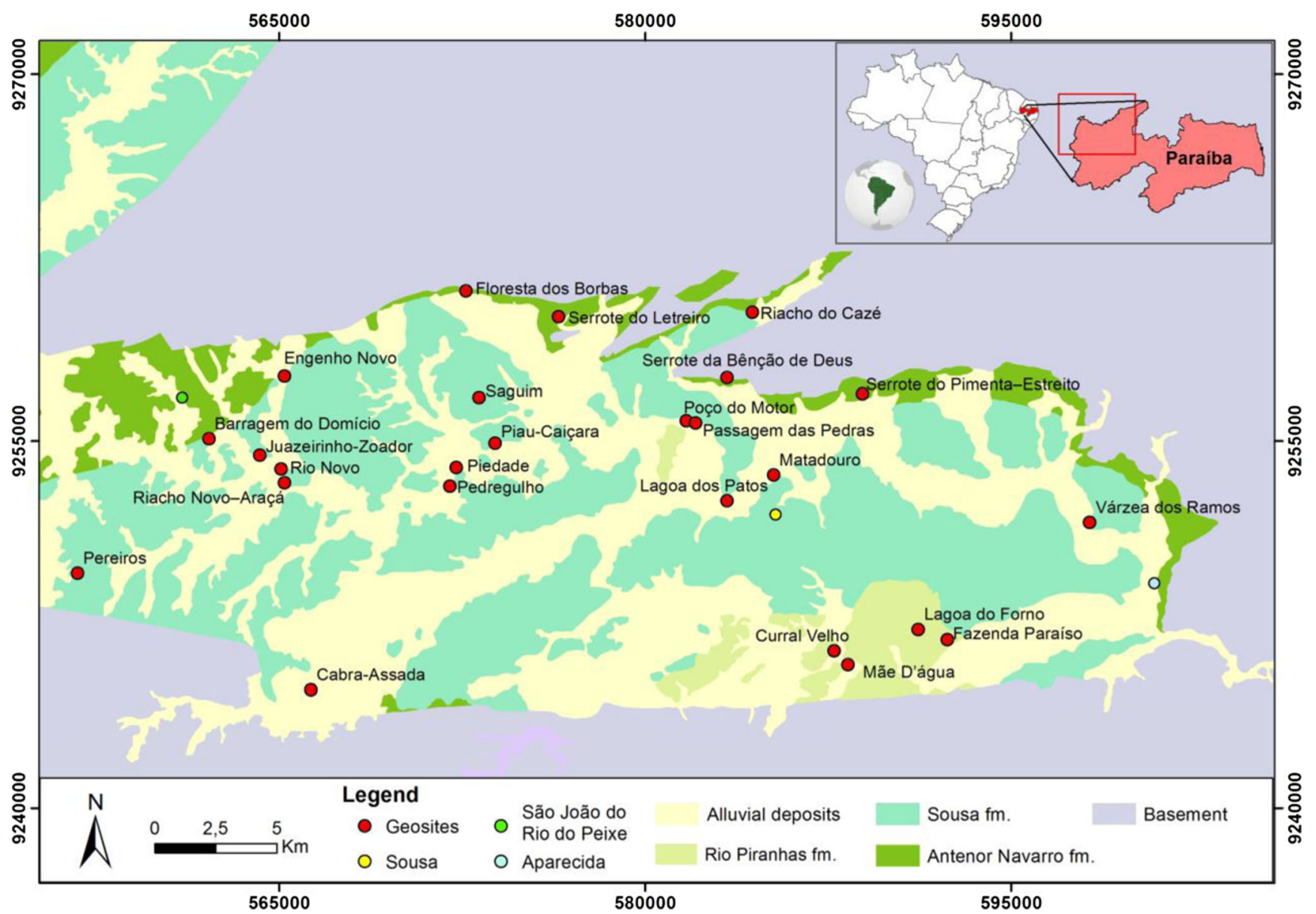

Fig. 2 Simplified geological map of the study area with location of palaeontological sites (after CPRM-Geological Survey of Brazil, sheet Sousa SB.24-ZA) 


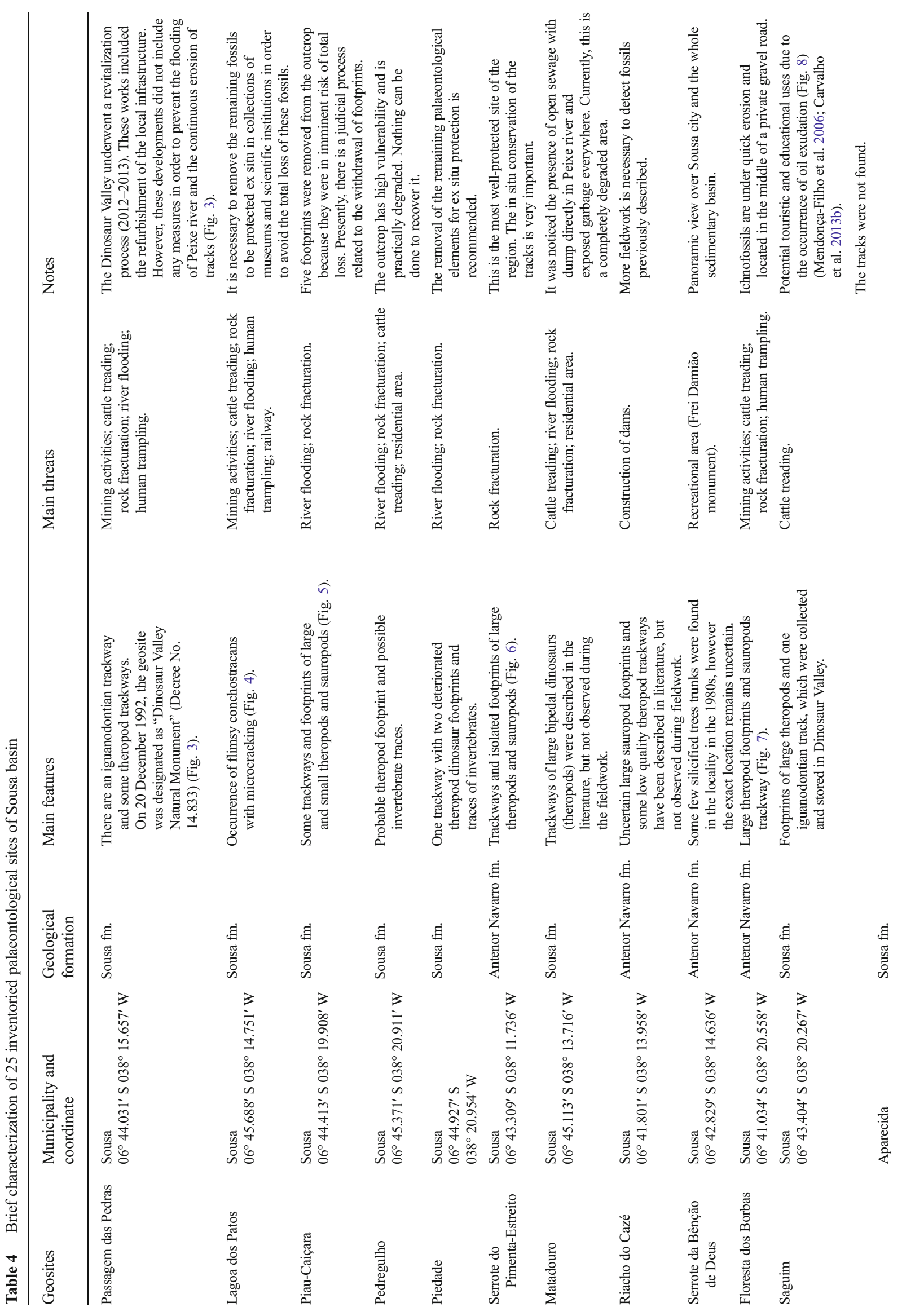




\begin{tabular}{|c|c|c|c|c|c|c|c|c|c|c|c|c|c|c|}
\hline$\frac{\mathscr{s}}{0}$ & 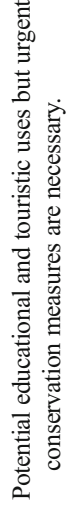 & 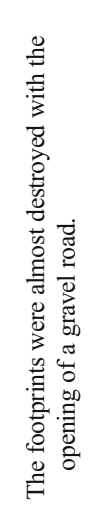 & 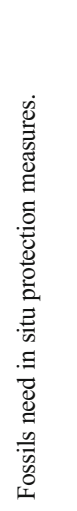 & 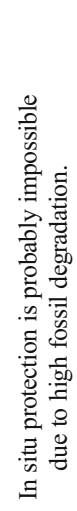 & 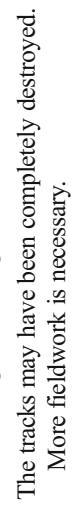 & 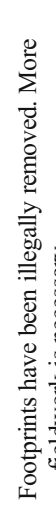 & 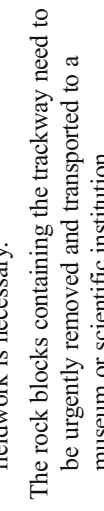 & 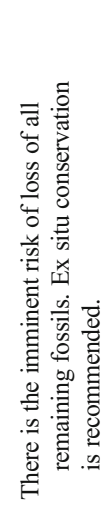 & 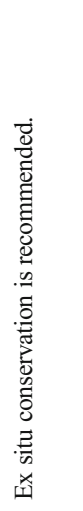 & 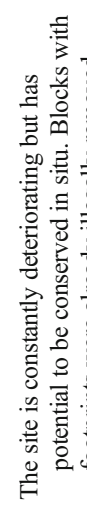 & 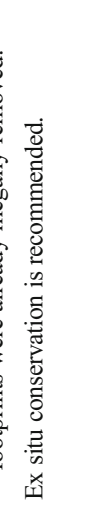 & 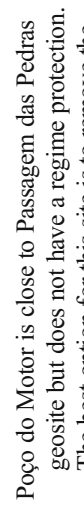 & 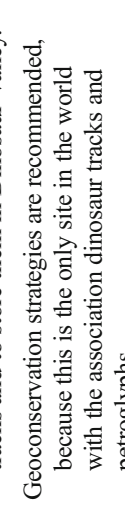 & 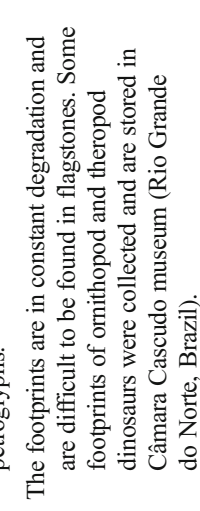 \\
\hline 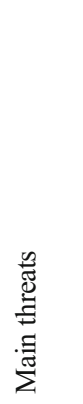 & 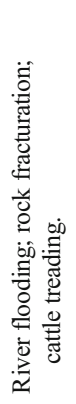 & 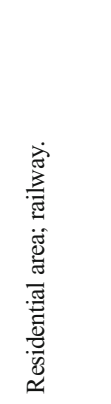 & 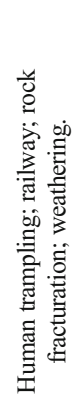 & 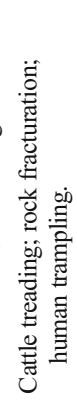 & 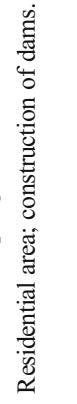 & 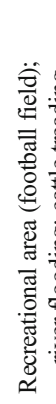 & 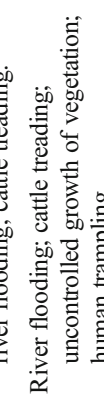 & 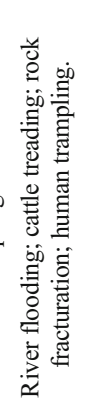 & 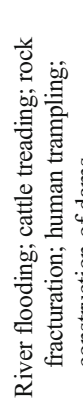 & 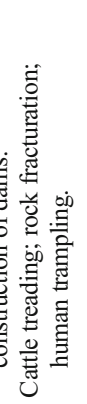 & 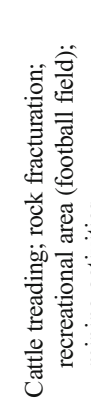 & 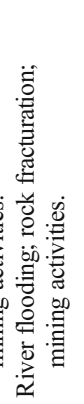 & 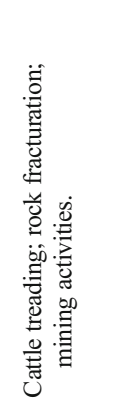 & 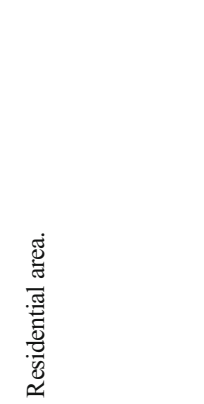 \\
\hline 悹 & 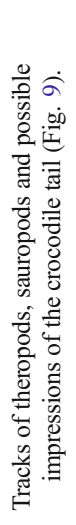 & 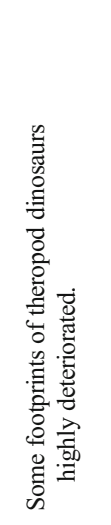 & 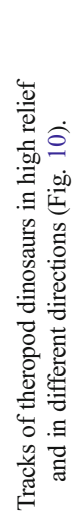 & 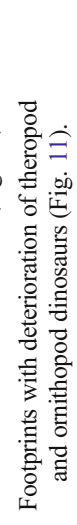 & 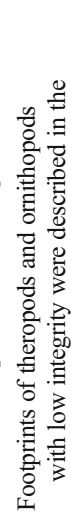 & 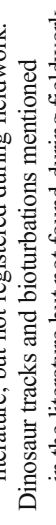 & 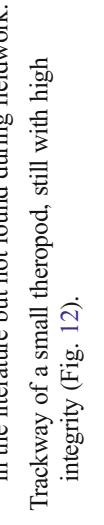 & 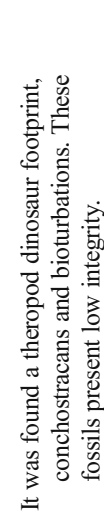 & 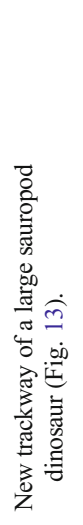 & 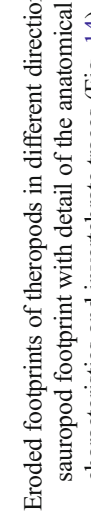 & 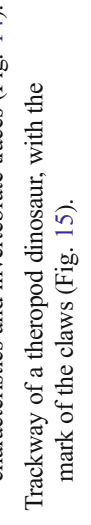 & 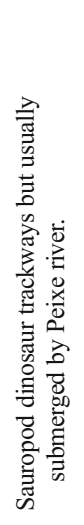 & 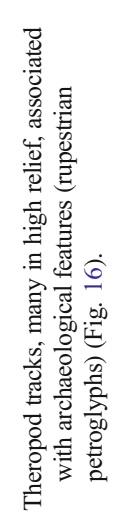 & 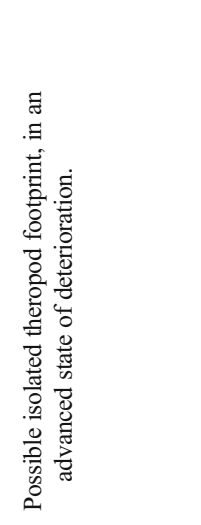 \\
\hline 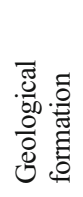 & & 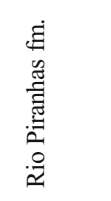 & 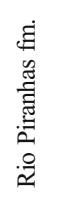 & 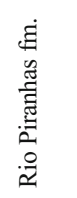 & 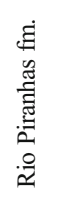 & 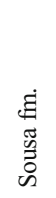 & 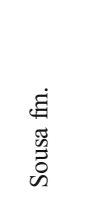 & 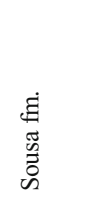 & & 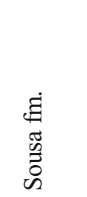 & 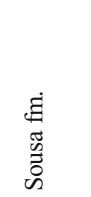 & $\begin{array}{l}\dot{\Xi} \\
\tilde{D} \\
\tilde{D} \\
\overline{0}\end{array}$ & 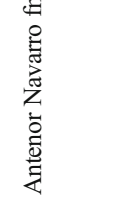 & 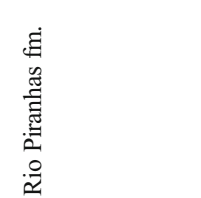 \\
\hline 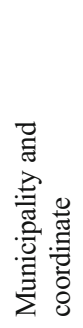 & & 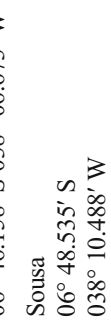 & 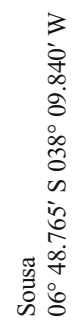 & 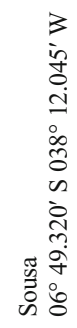 & 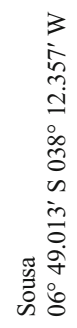 & $\begin{array}{l} \\
0 \\
0 \\
0 \\
0 \\
0 \\
0 \\
0 \\
0 \\
0 \\
0 \\
0 \\
0 \\
0 \\
0 \\
0 \\
0 \\
0 \\
0\end{array}$ & 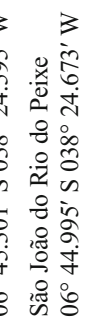 & 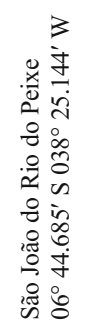 & 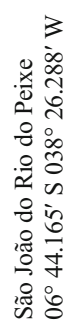 & 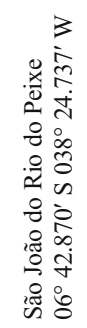 & 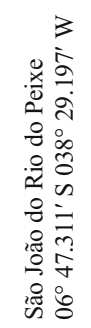 & 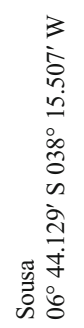 & 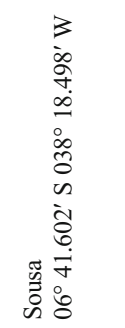 & 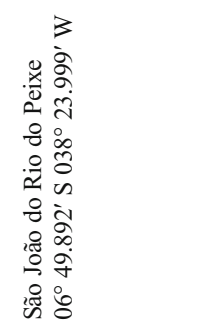 \\
\hline & 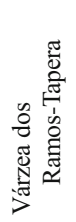 & 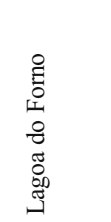 & 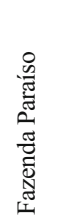 & 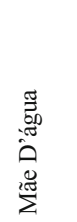 & 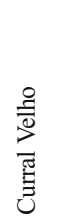 & $\stackrel{2}{\ddot{\alpha}}$ & 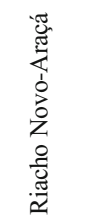 & 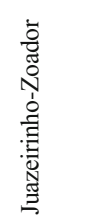 & 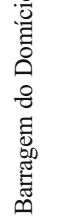 & 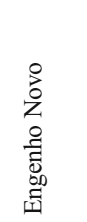 & 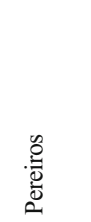 & $\begin{array}{l}8 \\
\sum_{0}^{0} \\
0 \\
0 \\
0 \\
0 \\
0 \\
0\end{array}$ & 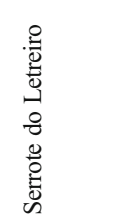 & 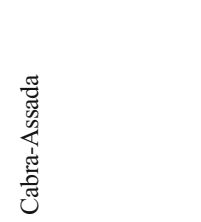 \\
\hline
\end{tabular}




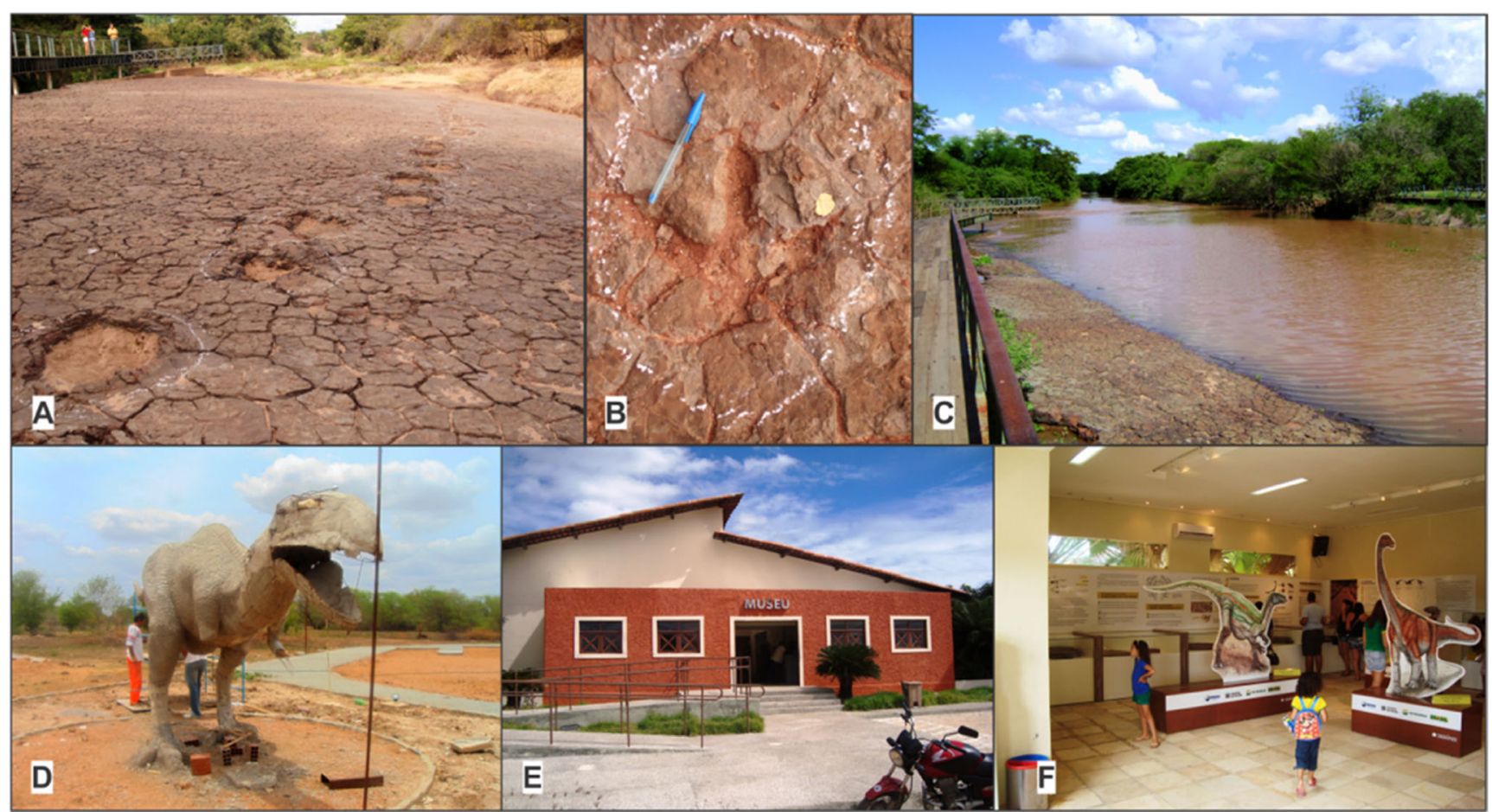

Fig. 3 Passagem das Pedras geosite. a, b Trackway of ornithopod dinosaur and footprint of theropod dinosaur. Note the presence of mud cracks (August 2010). c Overview of the geosite completely flooded, causing degradation of the trackways (March 2012). d Construction of a dinosaur replica in Dinosaur Valley (March 2013). e, f External and internal view of the museum. New exhibition with dinosaur replicas and interpretative panels (photographs by Tatiane Santos, June 2014) zero was assigned when a particular criterion did not reach the minimum score of 1 . Specifically for the scientific value (criteria 1 to 6 of Table 2), there is no score 3 in order to emphasize the results obtained from fossiliferous areas with score 4 (Brilha 2015). The final value for each geosite derives from the weighted sum of each criterion, with a maximum score of 400 points. Each criterion has a specific weight for the scientific value (SVW), educational value (EVW), touristic value (TVW) and vulnerability (VUW) (Table 2). Based on the numerical result, the scientific, educational and touristic values, and the vulnerability, of palaeontological sites were classified into one of four classes: very low, low, moderate and high (Table 3 ).

García-Ortiz et al. (2014) conducted a detailed description of the terms that evaluate the risk of degradation of a geosite: sensitivity, fragility, natural and anthropic vulnerability. To

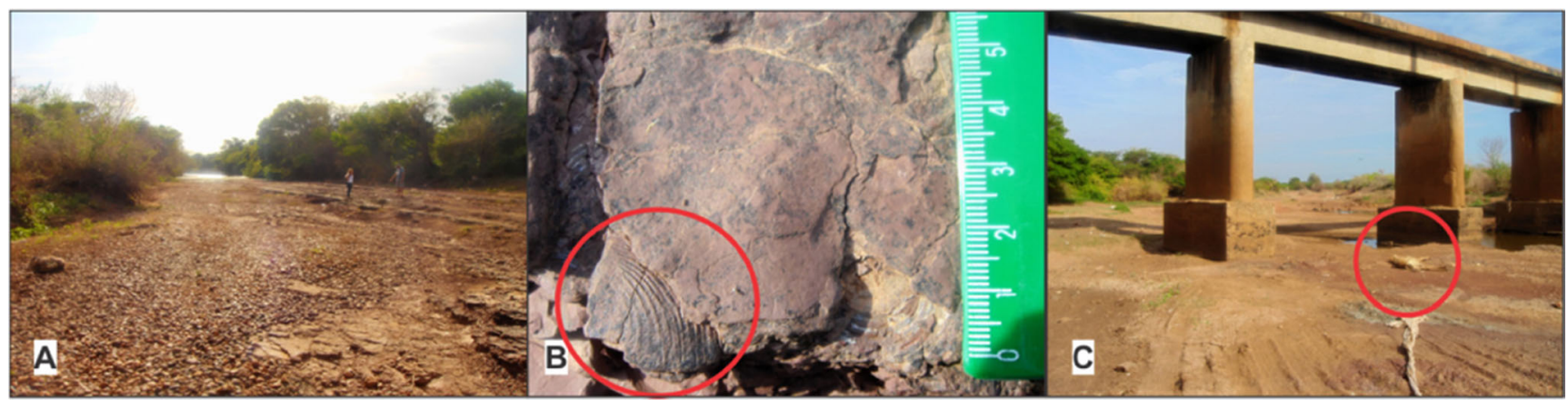

Fig. 4 Lagoa dos Patos geosite (March 2013). a Overview of Peixe river. b Fragile conchostracan with a microcracking. c Ruminant animal carcass and railway bridge near the site 


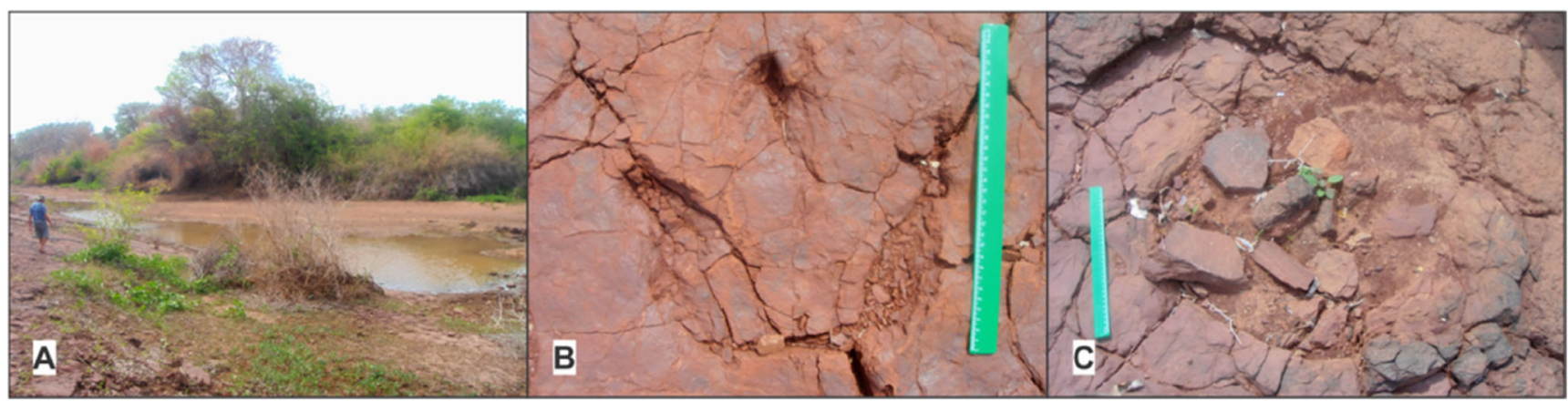

Fig. 5 Piau-Caiçara geosite (March 2013). a Overview of the geosite in the bed of Peixe river. b Theropod dinosaur footprints. c Sauropod dinosaur footprint

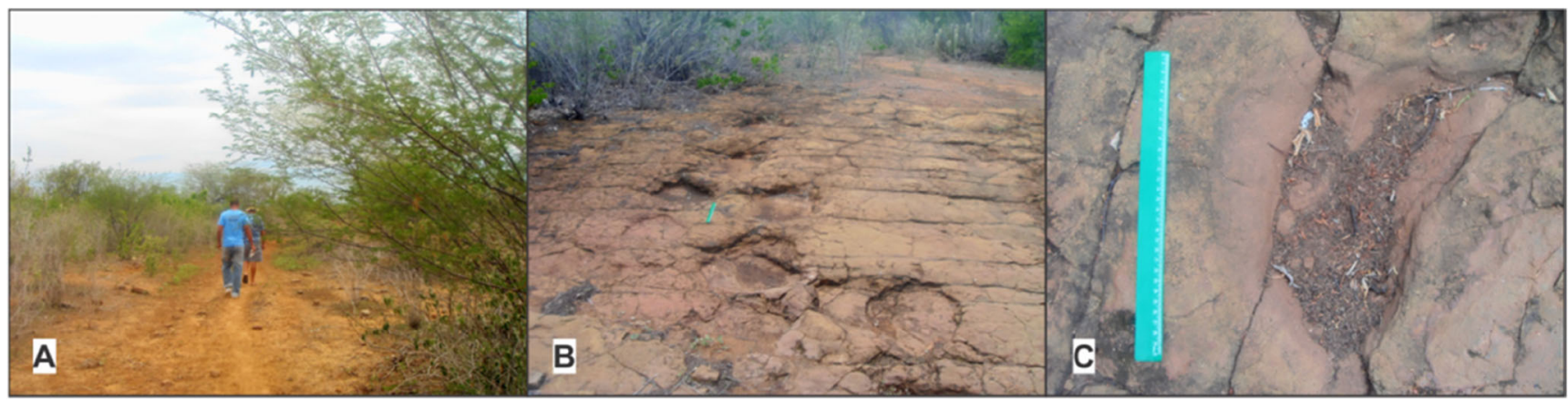

Fig. 6 Serrote do Pimenta-Fazenda Estreito geosite (March 2013). a Dirt road to access the geosite. b Sauropod dinosaur trackway. c Theropod dinosaur footprint

test the use of these terms, García-Ortiz et al. (2014) carried out an analysis of geosites in La Rioja (Spain), where more than 100 outcrops bearing exceptional dinosaur footprints are located. Thus, we use these terms to verify, in a general context, the risk of degradation of the palaeontological sites in Sousa basin.

\section{Inventory of Palaeontological Sites}

Twenty-five fossiliferous areas in the Sousa basin were inventoried: 17 in the Sousa municipality, 7 in São João do Rio do Peixe county and 1 in Aparecida county. Of those 25 geosites, 15 are outcrops of Sousa formation, 5 of Antenor

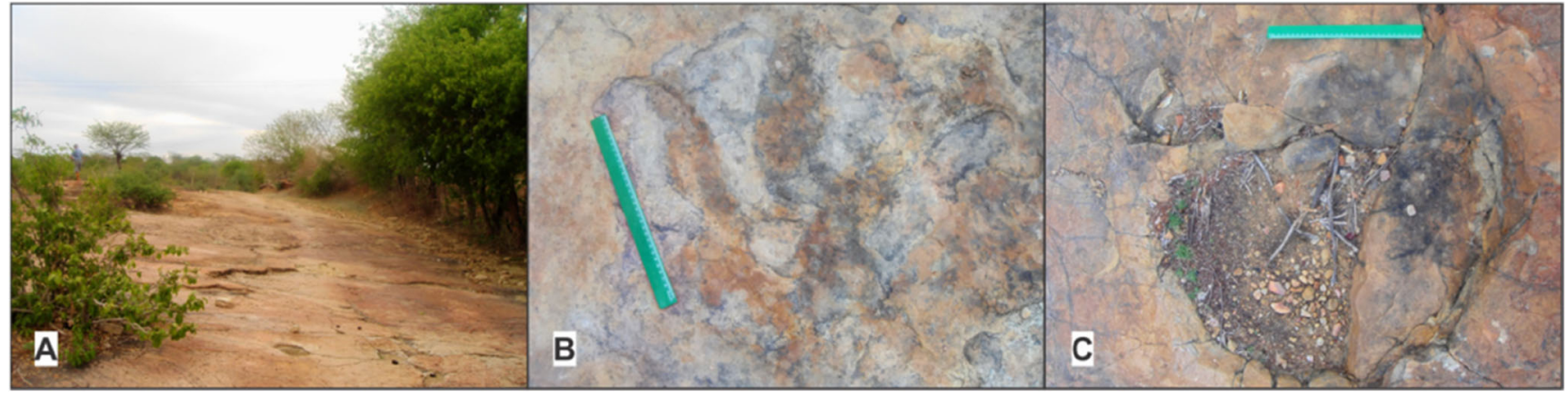

Fig. 7 Floresta dos Borbas geosite (March2013). a Private road where the fossil tracks occur. b Large theropod dinosaur footprint damaged by human and natural action. $\mathbf{c}$ Sauropod dinosaur footprint 


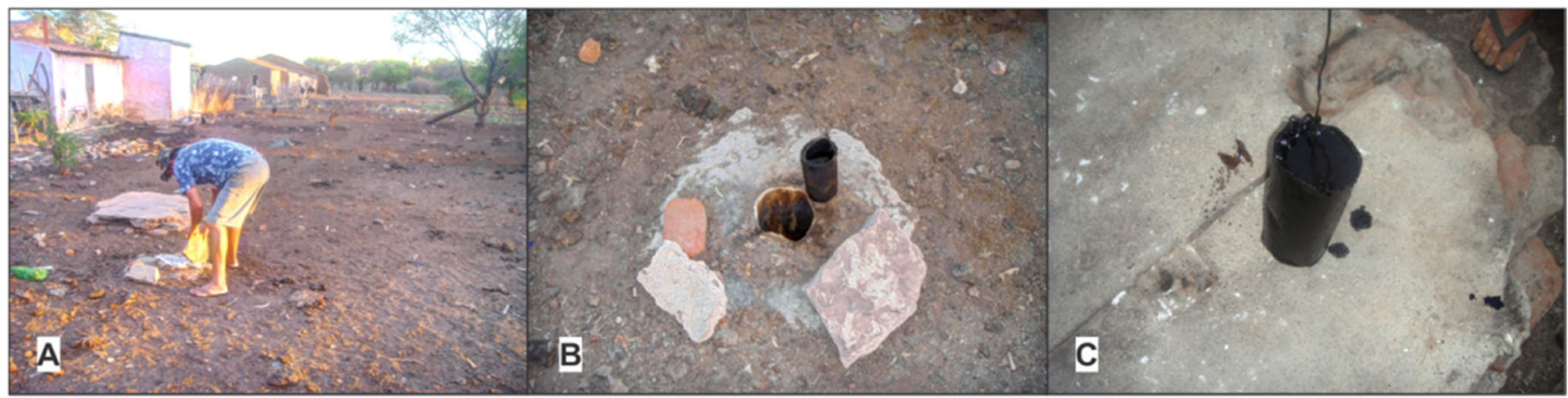

Fig. 8 Saguim geosite (March 2013). a General vision of the private property where the geosite is located. b, c Exudation of oil

Navarro formation and 5 of Rio Piranhas formation (Fig. 2 and Table 4). Geoconservation strategies for fossiliferous areas of the Sousa basin are not yet established, except for Passagem das Pedras geosite that is under a protection regime (Santos and Carvalho 2011). A brief description of all 25 inventoried palaeontological sites is presented in Table 4 (Figs. 3, 4, 5, 6, 7, 8, 9, 10, 11, 12, 13, 14, 15 and 16).

\section{Quantification of Palaeontological Sites}

The results of the numerical quantification of the scientific, educational and touristic values and of the vulnerability of the 25 geosites of the Sousa basin are presented in Table 5. The numerical results allowed the classification of all the geosites into one of four classes: very low, low, moderate and high value and vulnerability (Fig. 17 and Table 6).

In general, Sousa basin geosites are characterized by a low scientific value. Ten geosites have very low scientific value, 12 low, two moderate and one high scientific value (Passagem das Pedras geosite). These results are justified by the low integrity of many fossil sites and by the fact that they are common in the study area
(Sousa basin), have low fossil diversity (most sites have only dinosaur tracks) and absence of other geological features with significant relevance. However, the scientific importance of an area with more than 500 dinosaur tracks studied and mapped during approximately 40 years cannot be ignored. In addition, at the national scale of Brazil, the occurrence of dinosaur footprints is not so common, which is a justification for trying to understand the scientific importance of the study area in a national context.

The results of the assessment show that Sousa basin geosites are more suitable for an educational use when compared with a touristic use. A total of two geosites have a very low educational value, ten have low, 12 moderate and one high (Passagem das Pedras geosite), whilst four geosites have very low touristic value, 18 low and only three show moderate touristic value. Passagem das Pedras geosite, which already has had some geoconservation actions implemented and has the highest score for the scientific and educational values, did not reach a high touristic value.

In what concerns vulnerability, only one geosite has low vulnerability. Nine geosites have moderate, and 15 geosites have high vulnerability. The palaeontological

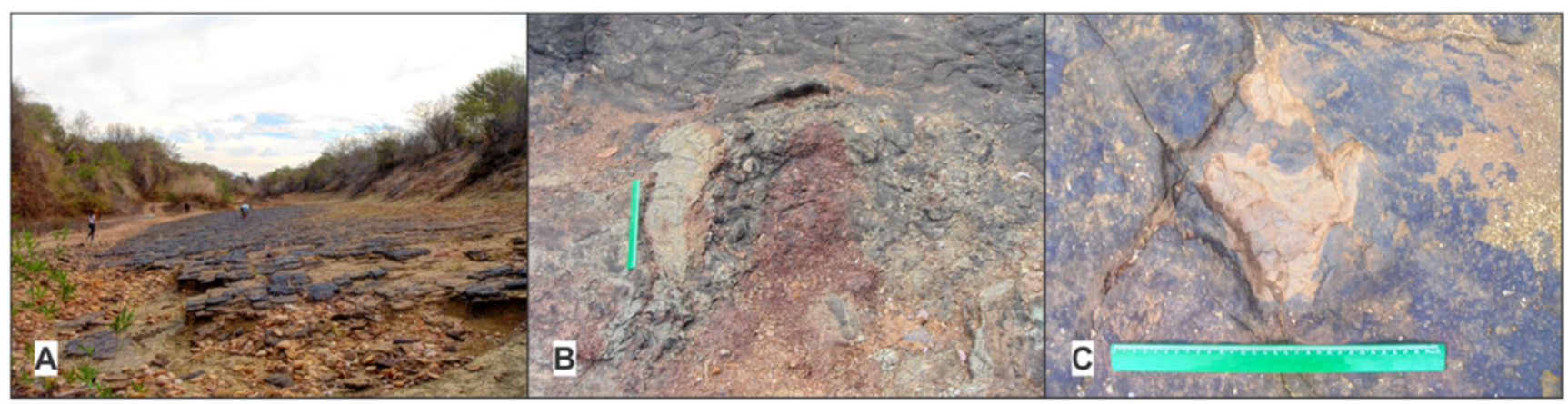

Fig. 9 Várzea dos Ramos-Tapera geosite (March 2013). a Overview of the outcrop containing ichnofossils and sedimentary structures. b Sauropod dinosaur footprint. c Theropod dinosaur footprint 


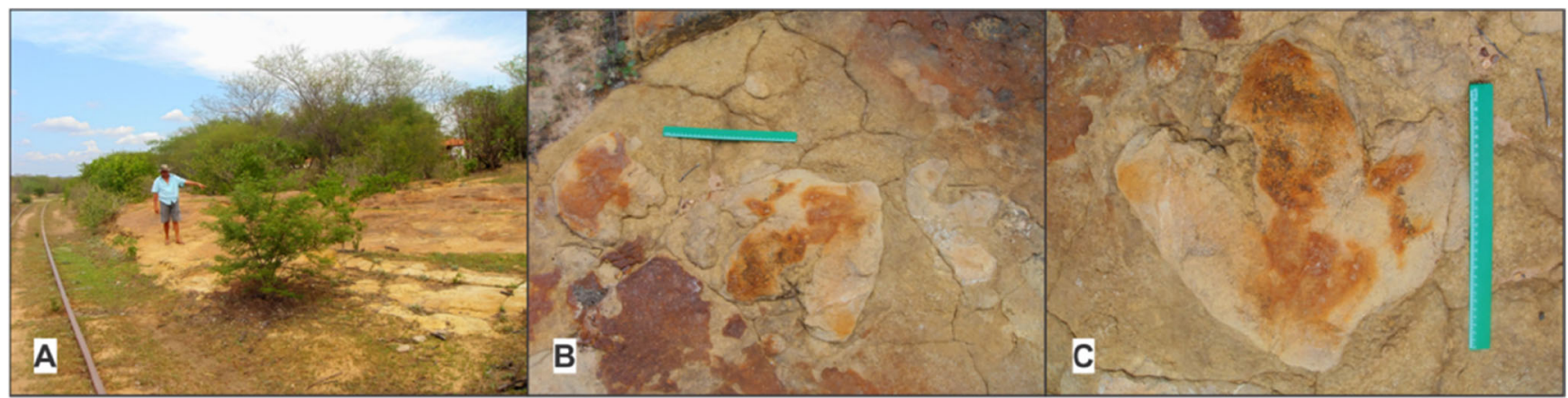

Fig. 10 Fazenda Paraíso geosite (March 2013). a Overview of the geosite close to the railway. b, c Theropod dinosaur footprints in high relief in sandstone slabs and in different directions. Note the evidences of oxidation processes

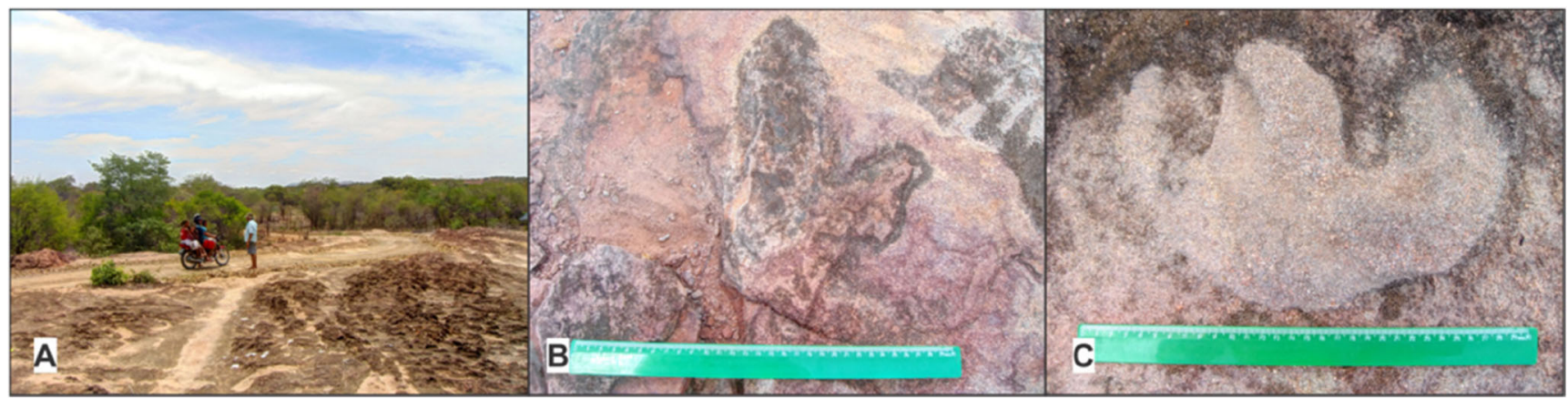

Fig. 11 Mãe D’Água geosite (March 2013). a Overview of geosite. b Theropod dinosaur footprint showing strong erosion effects. c Ornithopod dinosaur footprint (Iguanodonid)

sites of the Sousa basin are fragile because their fossils occur in fractured rocks and have natural vulnerability because they are located in areas under the influence of regular flooding caused by the rise of the Peixe river waters and by cattle trampling. In addition, these sites are under anthropic vulnerability due to mining and illegal collecting of fossils, together with the proximity of residential areas and roads, and not least that they oc-

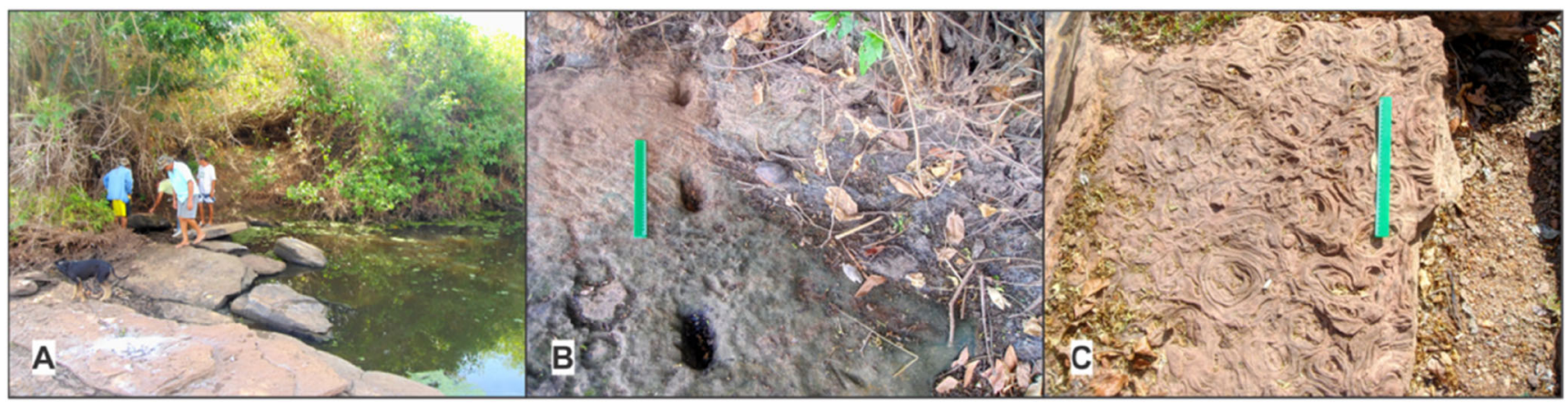

Fig. 12 Riacho Novo-Araça geosite (March 2013). a Overview of geosite highlighting the rocky blocks detached from the riverbed during the wet season. b Trackway of a small theropod dinosaur. c Fluidization structures 


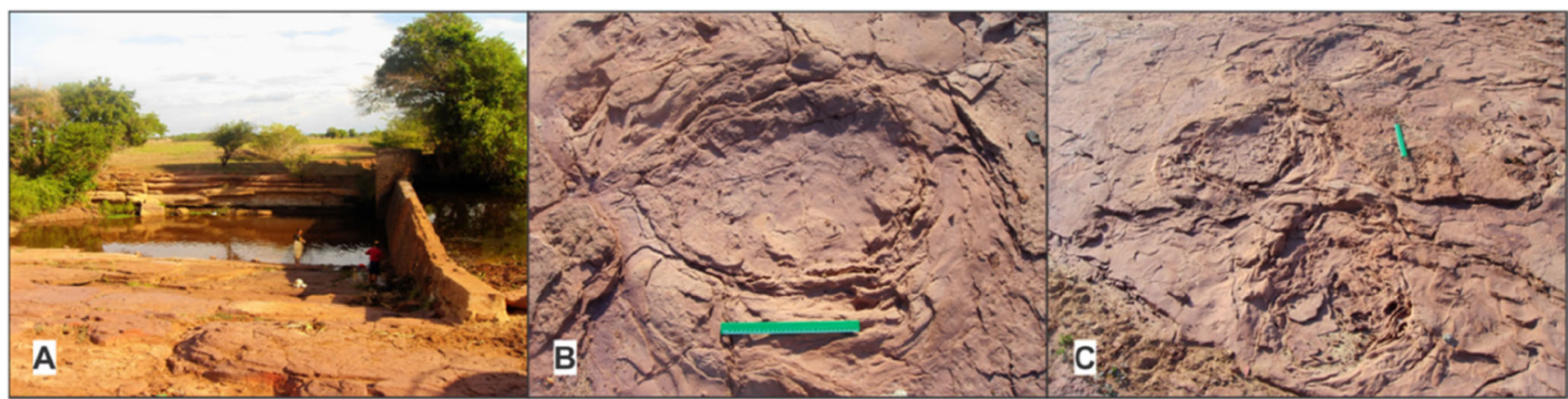

Fig. 13 Barragem do Domício geosite (March 2013). a View of the dam built to store water. b, c New sauropod dinosaur trackway discovered during fieldwork

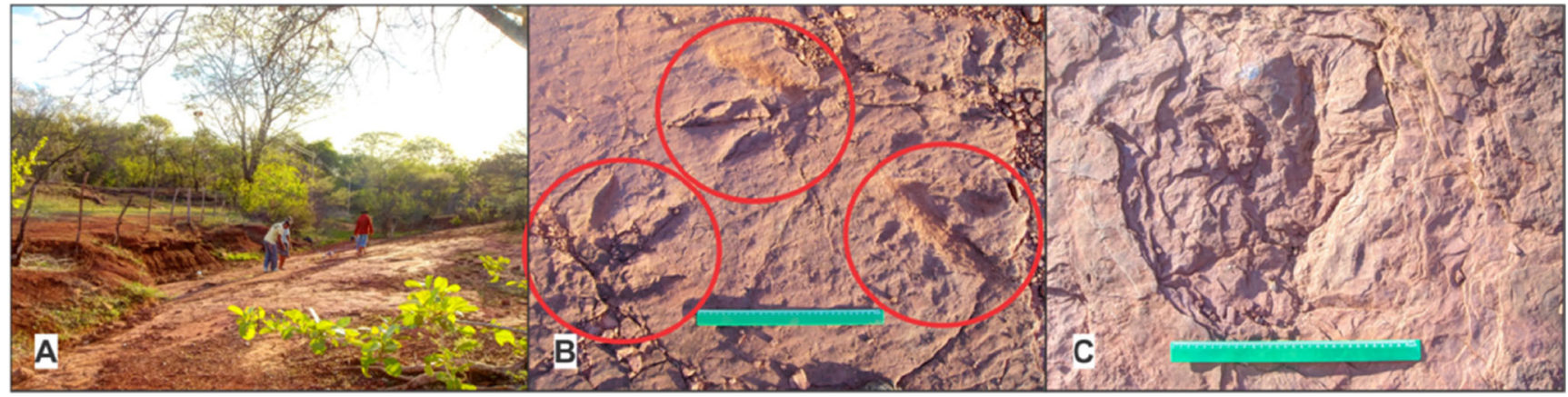

Fig. 14 Engenho Novo geosite (March 2013). a General overview of slabs with footprints. b Theropod dinosaur footprints in three different positions. c Sauropod dinosaur footprint

cupy small areas, which is a risk factor as indicated by Fuertes-Gutiérrez and Fernández-Martínez (2010).

As observed by García-Ortiz et al. (2014), the smaller and shallower dinosaur tracks are more sensitive than larger and deeper. In the Sousa basin, there are large and shallow dinosaur tracks (Floresta dos Borbas), large and deep (Passagem das Pedras), small and deep (Riacho Novo-Araçá) and in diverse sizes and in high relief (Serrote do Letreiro). Another issue is that due to their occurrence in siliciclastic rocks, ichnofossils can suffer from microcracking (Lagoa dos Patos) and oxidation processes (Fazenda Paraíso). In general, the Sousa geosites were discovered between 1970 and 1980 and fossils were described as having a high integrity. Today, some geosites are already damaged, which suggests that the Sousa fossils are being degraded by anthropic and natural causes at a very high rate.

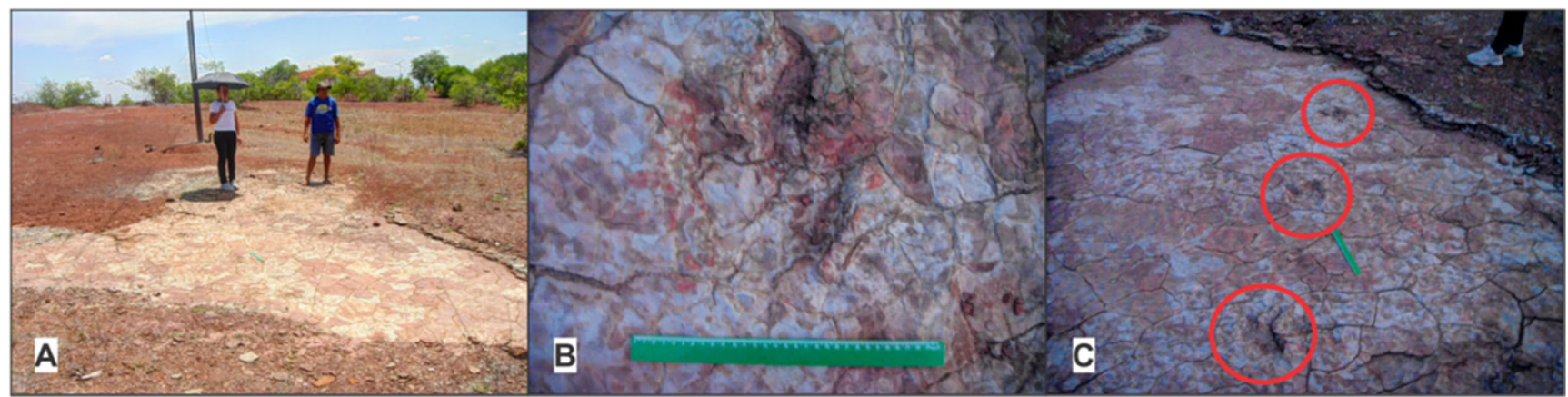

Fig. 15 Pereiros geosite (March 2013). a View of the slab with the trackway. b Theropod dinosaur footprint still intact and with the claw mark. c Theropod dinosaur trackway 


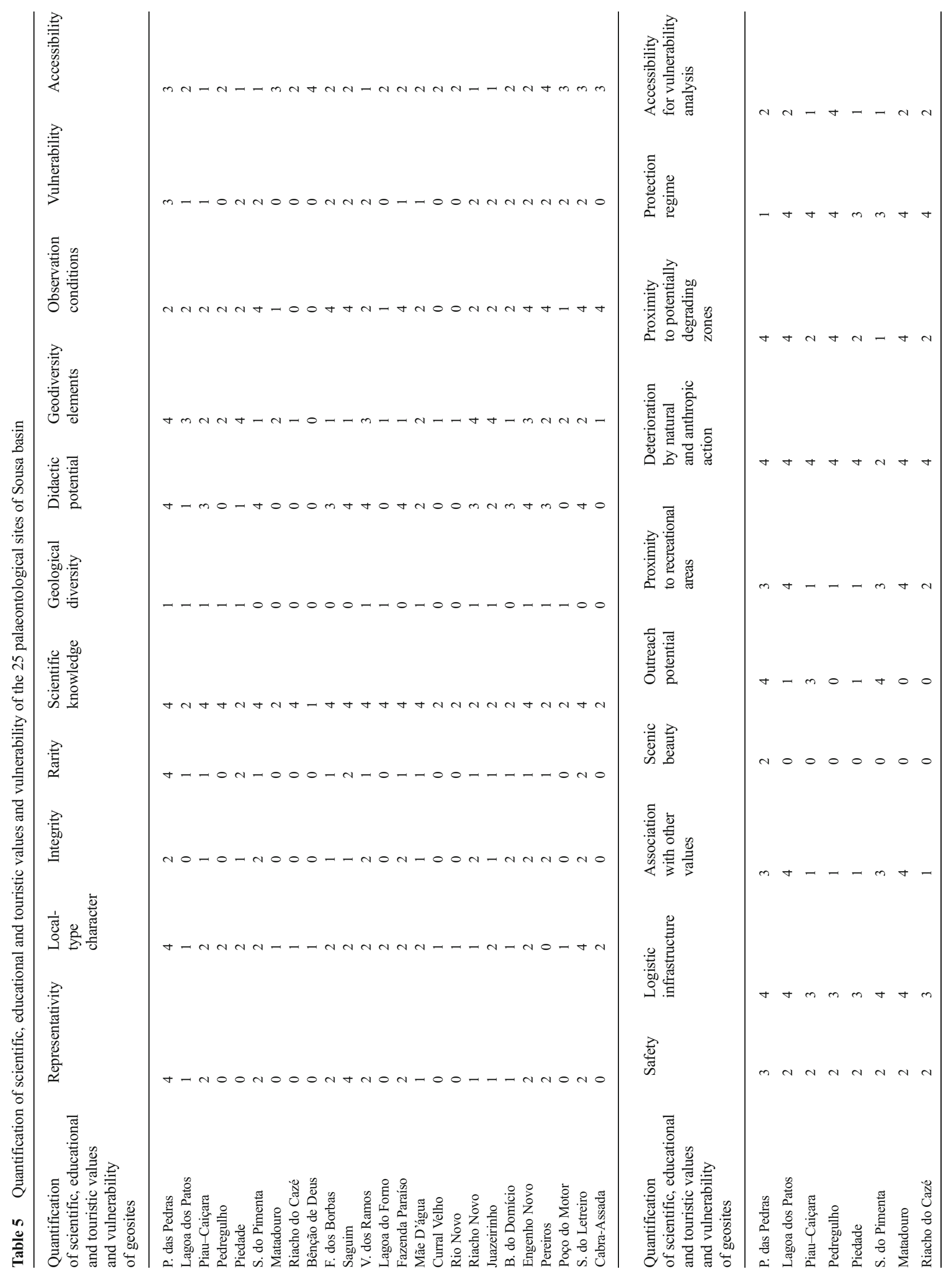




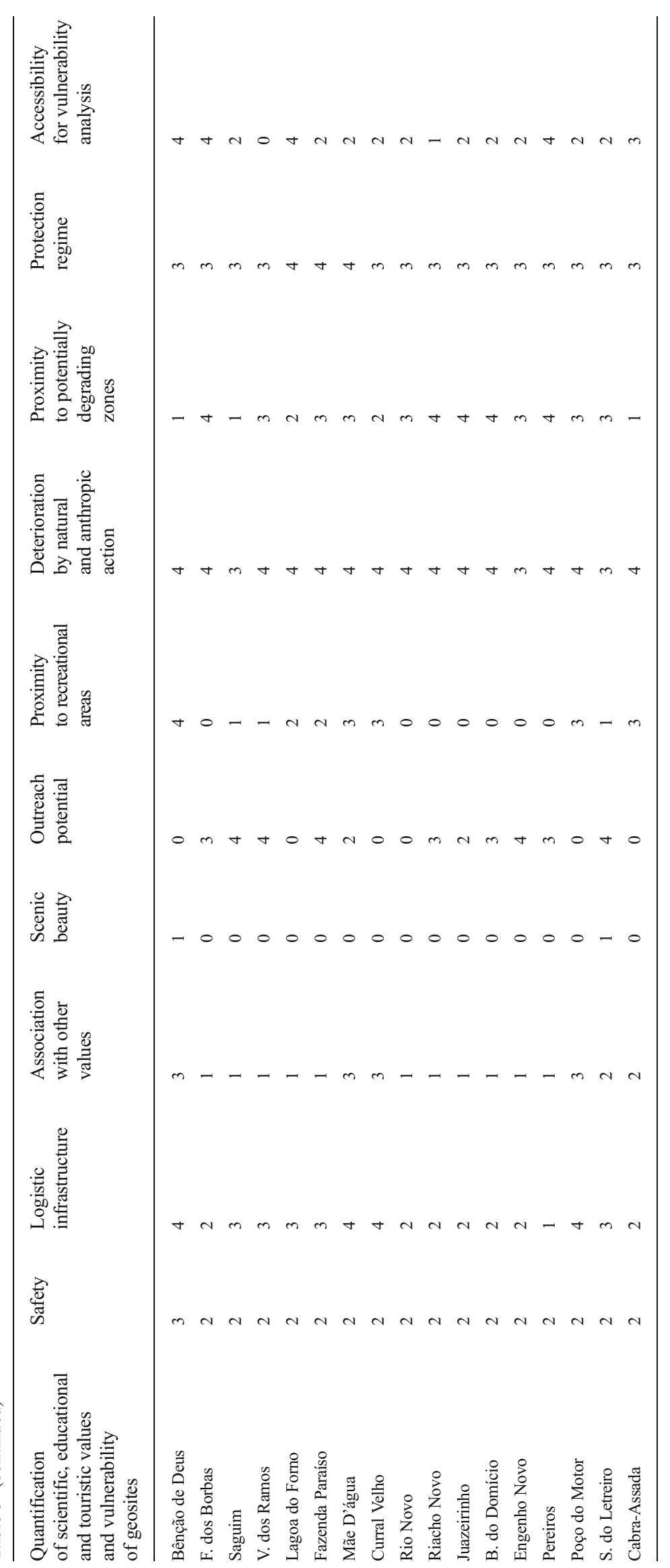




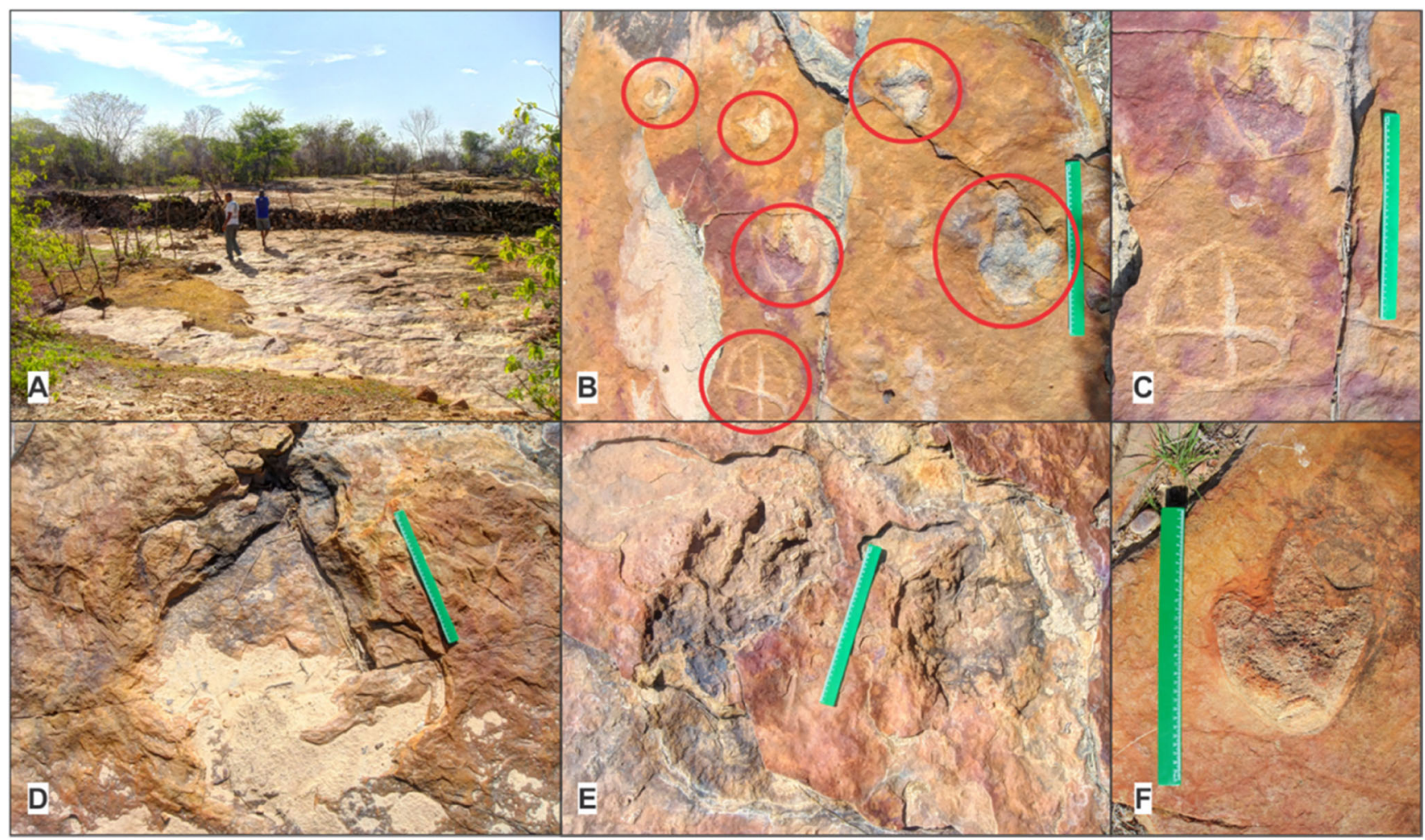

Fig. 16 Serrote do Letreiro geosite (March 2013). a Overview of geosite. b, c Theropod dinosaur footprints associated with petroglyphs. Note the rock fracturing. $\mathbf{d}$ Track of a large theropod dinosaur discovered during fieldwork. $\mathbf{e}$ Theropod dinosaur footprint. $\mathbf{f}$ Theropod dinosaur footprint in high relief

\section{Conclusions}

The results of the inventory and assessment of 25 geosites in the Sousa basin provide support for the establishment of a strategy to protect the palaeontological heritage of the region. Concerning the results of the quantification, conclusions are that, in general, Sousa basin geosites have a low scientific and touristic values, moderate educational value and high vulnerability. Only in the Passagem das Pedras geosite have conservation and dissemination measures been implemented, but they are not yet effective for protecting the fossils.

Regarding the management of the Sousa geosites, five categories can be established. In the first category is Passagem das Pedras geosite, which is the only one where geoconservation strategies are already implemented. In the second category, there are six geosites which are still intact and therefore with the possibility of being conserved in situ: Serrote do Pimenta-Estreito, Várzea dos Ramos-Tapera, Fazenda Paraíso, Engenho Novo, Serrote do Letreiro and Saguim.

The third category includes two fossiliferous areas that already show considerable deterioration, thus making it necessary to rapidly decide whether to conserve the fossils in situ or ex situ: Piau-Caiçara e Floresta dos Borbas. In the fourth category, there are eight geosites which the fossils should be conserved ex situ: Riacho Novo-Araçá, Barragem do Domício and Pereiros (these three have a low number of fossil occurrences) and Lagoa dos Patos, Piedade, Mãe D'água, Juazeirinho-Zoador and Poço do Motor (the last five are being rapidly destroyed).

Finally, in the fifth category, there are four geosites where fossils have a very high degree of deterioration (Pedregulho, Lagoa do Forno, Cabra-Assada and Matadouro), together with another four geosites where no fossils were found during the present fieldwork, which justifies a need to carry out more fieldwork (Riacho do Cazé, Serrote da Bênção de Deus, Curral Velho and Rio Novo) - we should not assume that sites where no fossils were found have lost their scientific value because ongoing process of erosion that may have caused the disappearance of dinosaur footprints can also reveal new tracks elsewhere in the same formation in the area. For this reason, all 25 identified palaeontological sites were still inventoried and quantified.

Two of the 25 geosites have another type of geological relevance besides palaeontological: the Serrote da Bênção de Deus geosite provides a panoramic perspective of Sousa city and of the surrounding sedimentary basin and the Saguim geosite where an oil seep (rare in the region) can be easily observed.

The Sousa basin is included in the Brazilian Geoparks Programme. However, only taking into account the status of the palaeontological sites of the region, it is clear that, currently, the area has a low potential to become a geopark, mainly 

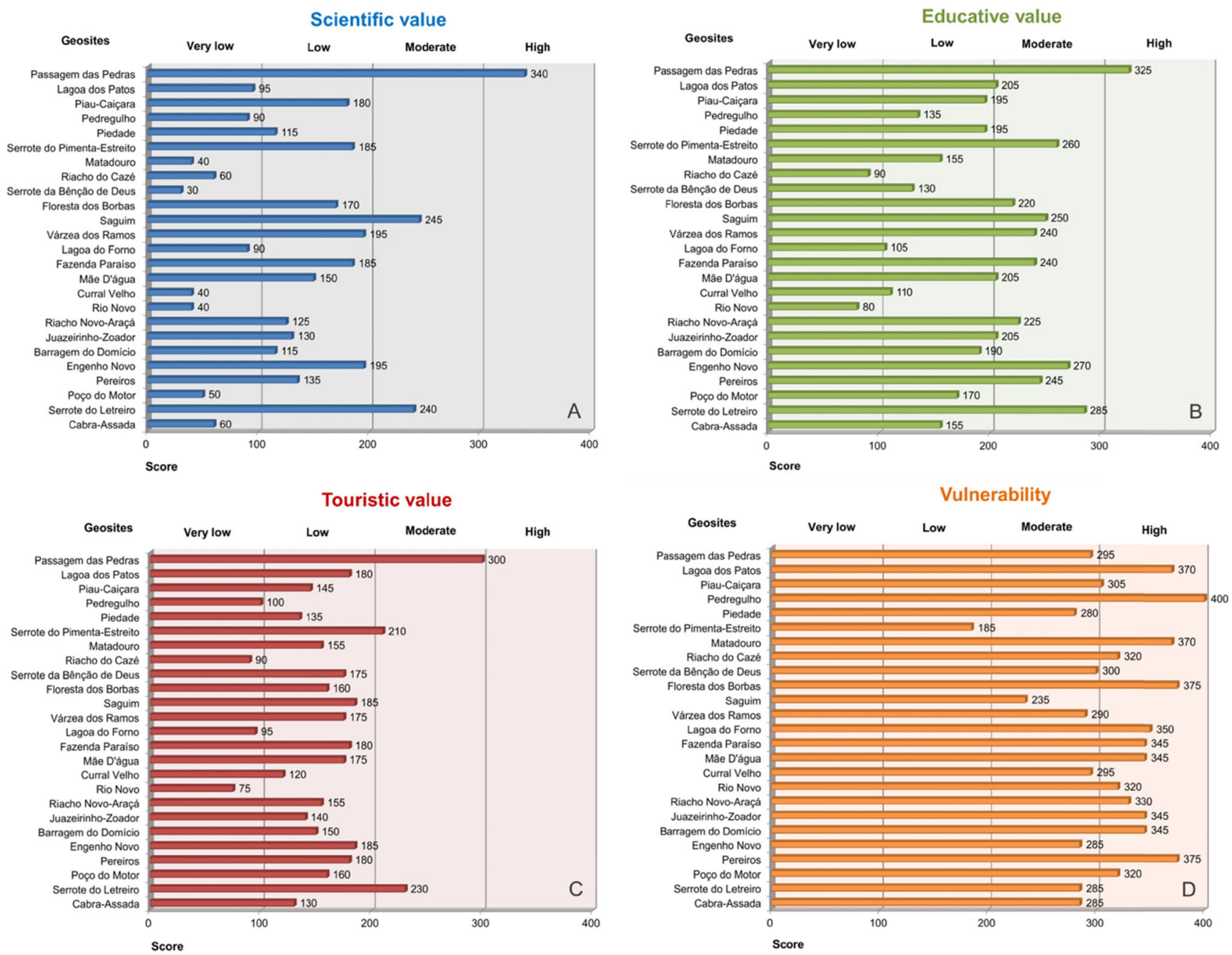

Fig. 17 Final scores of palaeontological sites and suitability in each of the classes: very low, low, moderate and high. a Scientific value. b Educational value. c Touristic value. d Vulnerability

due to a low scientific and touristic values and to a high vulnerability of the majority of the geosites (some geosites no longer exhibit any palaeontological record or have significantly deteriorated geological elements).

However, sites that still have conditions to be conserved in situ could support a future geopark application if

Table 6 Number of palaeontological sites that have scientific, educational and touristic values and vulnerability in each of the classes: very low, low, moderate and high

\begin{tabular}{lllll}
\hline Topic & $\begin{array}{l}\text { Very low } \\
0-100\end{array}$ & $\begin{array}{l}\text { Low } \\
101-200\end{array}$ & $\begin{array}{l}\text { Moderate } \\
\text { 201-300 }\end{array}$ & $\begin{array}{l}\text { High } \\
301-400\end{array}$ \\
\hline Scientific value & 10 & 12 & 2 & 1 \\
Educational value & 2 & 10 & 12 & 1 \\
Touristic value & 4 & 18 & 3 & 0 \\
Vulnerability & 0 & 1 & 9 & 15 \\
\hline
\end{tabular}

complementary features are included in the geopark strategy, such as elements with ecological and cultural values. Additionally, partnerships between local administration, private companies and scientific institutions should be implemented, which can seek to raise financial support for the conservation of the Sousa fossils. As many geosites of the Sousa basin are located on private land, it is very important to establish agreements with the owners to guarantee the future implementation of scientific, educational and touristic uses of these areas. It is also necessary to develop educational and touristic programmes and a management structure with capacity to operate in the territory and establish community involvement with the project.

The ex situ conservation of Sousa fossils should be carried out in an appropriate institution within the 'Dinosaur Valley' area, in order to retain the fossils in the region where they were found and to make the more representative examples available to students and the general public. 
We can conclude that the Sousa basin is an excellent example of an area that is losing its potential to become a geopark because geoconservation strategies have not been implemented at the geosites, which makes the palaeontological heritage very vulnerable. The trend is that all the geosites could be destroyed in a human timescale if no urgent conservation actions are established. A management plan for the fossiliferous areas that still have potential to be conserved in situ needs to be prepared and implemented by the authorities.

Acknowledgments Thanks are due to Marcelo Bueno de Abreu and Gustavo Ferreira de Oliveira for their help in preparing the illustrations. This study was supported by CNPq, CAPES and FAPERJ.

\section{References}

Brilha JB (2015) Inventory and quantitative assessment of geosites and geodiversity sites: a review. Geoheritage 1:1-16

Carvalho IS (1989) Icnocenoses continentais: bacias de Sousa, UiraúnaBrejo das Freiras e Mangabeira. Dissertation, Universidade Federal do Rio de Janeiro.

Carvalho IS (1993) Os conchostráceos fósseis das bacias interiores do Nordeste do Brasil. PhD thesis, Universidade Federal do Rio de Janeiro

Carvalho IS (1996a) As pegadas de dinossauros da Bacia de UiraúnaBrejo das Freiras (Cretáceo Inferior, Estado da Paraíba). In: Simpósio sobre o Cretáceo do Brasil, 4, Águas de São Pedro-SP, p $115-121$

Carvalho IS (1996b) Paleogeographic distribution of esthereliidean conchostraceans on the Cretaceous rift interior basins of Northeastern Brazil. In: Congresso Brasileiro de Geologia, 39, Salvador, Anais, 7: 387-389

Carvalho IS (2000a) Huellas de saurópodos de la Formación Antenor Navarro (Cretácico Temprano de la Cuenca de Sousa), Serrote do Letreiro, Paraíba, Brasil. Ameghiniana 37(3):353-362

Carvalho IS (2000b) Geological environments of dinosaur footprints in the intracratonic basins of northeast Brazil during the Early Cretaceous opening of the South Atlantic. Cretac Res 21:255-267

Carvalho IS (2004) Dinosaur footprints from Northeastern Brazil: taphonomy and environmental setting. Ichnos 11:311-321

Carvalho IS, Carvalho MGP (1990) O significado paleoambiental dos conchostráceos da Bacia de Sousa. In: Simpósio sobre a Bacia do Araripe e Bacias Interiores do Nordeste, 1, Crato-PE, anais, pp 329 333

Carvalho IS, Leonardi G (1992) Geologia das bacias de Pombal, Sousa, Uiraúna-Brejo das Freiras e Vertentes (Nordeste do Brasil). An Acad Bras Cienc 64(3):231-252

Carvalho IS, Borghi L, Leonardi G (2013a) Preservation of dinosaur tracks induced by microbial mats in the Sousa Basin (Lower Cretaceous), Brazil. Cretac Res 44:112-121

Carvalho IS, Mendes JC, Costa T (2013b) The role of fracturing and mineralogical alteration of basement gneiss in the oil exhsudation in the Sousa Basin (Lower Cretaceous), Northeastern Brazil. J S Am Earth Sci 47:47-54

Fernandes ACS, Carvalho IS (1997) Icnofósseis de invertebrados da bacia de Sousa (estado da Paraíba, Brasil): a localidade de Serrote do Letreiro. In: Simpósio sobre a Bacia do Araripe e Bacias
Interiores do Nordeste, 2, Crato-PE, resumo das comunicações, pp $147-155$

Ferreira RV, Silva RC, Siqueira LMP, Schobbenhaus C (2014) Proposta de criação do geoparque Rio do Peixe, PB. In: Congresso Brasileiro de Geologia, 47, Salvador, anais, pp 142

Fuertes-Gutiérrez I, Fernández-Martínez E (2010) Geosites inventory in the Leon Province (Northwestern Spain): a tool to introduce geoheritage into regional environmental management. Geoheritage 2:57-75, http://dx.doi.org/10.1007/ s12371-010-0012-y

García-Ortiz E, Fuertes-Gutiérrez I, Fernández-Martínez E (2014) Concepts and terminology for the risk of degradation of geological heritage sites: fragility and natural vulnerability, a case study. The Geologists' Assoc 125(4):463-479

Godoy LC, Leonardi G (1985) Direções e comportamento dos dinossauros da localidade de Piau, Sousa, Paraíba (Brasil), Formação Sousa (Cretáceo Inferior). In: Brasil, DNPM, Coletânea de Trabalhos Paleontológicos, 27, Brasília, Seção Paleontologia e Estratigrafia, 2: 65-73 (Série Geologia)

IBGE (2010a) Cidades. http://www.ibge.gov.br/cidadesat/topwindow. htm?1. Accessed 20 August 2014

IBGE (2010b) Estados. http://www.ibge.gov.br/estadosat/perfil.php? sigla $=\mathrm{pb}$. Accessed 20 August 2014

Leonardi G (1979a) Nota Preliminar Sobre Seis Pistas de Dinossauros Ornithischia da Bacia do Rio do Peixe (Cretáceo Inferior) em Sousa, Paraíba, Brasil. An Acad Bras Cienc 51(3):501-516

Leonardi G (1979b) New Archosaurian trackways from the Rio do Peixe Basin, Paraíba, Brazil. Annali dell’Universitat di Ferrara 5(14):239249

Leonardi G (1987) Pegadas de dinossauros (Carnosauria, Coelurosauria, Iguanodontidae) na Formação Piranhas da Bacia do Rio do Peixe, Sousa, Paraíba, Brasil. In: Congresso Brasileiro de Paleontologia, 10, Rio de Janeiro, anais, 2 vol., 1: 337-351

Leonardi G (1989) Inventory and statistics of the South American dinosaurian ichnofauna and its paleobiological interpretation. In: Gillette DD, Lockley MG (eds) Dinosaur tracks and traces. Cambridge University Press, p 165-178

Leonardi G, Carvalho IS (2002) Icnofósseis da Bacia do Rio do Peixe, PB - O mais marcante registro de pegadas de dinossauros do Brasil. In: Winge M, Schobbenhaus C, Campos DA, Berbert-Born M, Queiroz ET (eds) Sítios Geológicos e Paleontológicos do Brasil. http://www. unb.br/ig/sigep/sitio026/sitio026.pdf. Accessed 15 August 2014

Leonardi G, Carvalho IS (2007) Dinosaur Ichnocoenosis from Sousa and Uiraúna-Brejo das Freiras Basins, Northeast Brazil, In: Carvalho IS et al. (eds) Paleontologia: Cenários de Vida. Editora Interciência, p 363-377

Leonardi G, Santos MFCF (2004) New dinosaur tracksites from the Sousa Lower Cretaceous basin (Paraíba, Brasil). Studi Trent Sci Nat Acta Geol 81:5-21

Leonardi G, Lima CV, Lima FHO (1987a) Os dados numéricos relativos às pistas (e suas pegadas) das Icnofaunas dinossaurianas do Cretáceo inferior da Paraíba, e sua interpretação estatística. I - Parâmetros das pistas. In: Congresso Brasileiro de Paleontologia, 10, Rio de Janeiro, anais, 2 vol., 1: 377-394

Leonardi G; Lima CV, Lima FHO (1987b) Os dados numéricos relativos às pistas (e suas pegadas) das Icnofaunas dinossaurianas do Cretáceo inferior da Paraíba, e sua interpretação estatística. II - Parâmetros das pegadas. In: Congresso Brasileiro de Paleontologia ,10, Rio de Janeiro, anais, 2 vol., 1: 395-417

Leonardi G, Lima CV, Lima FHO (1987c) Os dados numéricos relativos às pistas (e suas pegadas) das Icnofaunas dinossaurianas do Cretáceo inferior da Paraíba, e sua interpretação estatística. III - Estudo estatístico. In: Congresso Brasileiro de Paleontologia, 10, Rio de Janeiro, anais, 2 vol., 1: 419-444

Lima MR, Coelho MPCA (1987) Estudo palinológico da sondagem da Lagoa do Forno, Bacia do Rio do Peixe, Cretáceo do Nordeste do 
Brasil. Boletim do Instituto de Geociências USP, 18: 67-83 (Série Científica)

Mampel L, Cobos A, Alcalá L, Luque L, Royo-Torres R (2009) An integrated system of heritage management applied to dinosaur sites in Teruel (Aragón, Spain). Geoheritage 1:53-73

Mendonça Filho JG, Carvalho IS, Azevedo DA (2006) Aspectos geoquímicos do óleo da Bacia de Sousa (Cretáceo Inferior), Nordeste do Brasil: contexto geológico. Geociências 25(1):91-98

Moraes LI (1924) Serras e Montanhas do Nordeste. In: Inspectoria de Obras Contra as Secas, Rio de Janeiro, Ministério da Viação e Obras Públicas, 2a. ed., Coleção Mossoroense, Fundação Guimarães Duque, 35(1): 43-58 (Série I. D. Plub. 58)

PNUD (2000) Tabelas de ranking do IDH-M. http://www.pnud.org.br/ atlas/tabelas/index.php. Accessed 20 August 2014

Santos WFS (2014) Sítios paleontológicos, estratégias de geoconservação e geoturismo na Bacia de Sousa (Paraíba): potencial da área para se tornar um geoparque. $\mathrm{PhD}$ thesis, Universidade Federal do Rio de Janeiro

Santos WFS, Carvalho IS (2011) Conservação do patrimônio geológico de Sousa, Paraíba (Brasil): importância científica, educacional e geoturística. In: Simposio de Geoparques Y Geoturismo em Chile, 1, Melipeuco, actas, pp 131-134

Santos MFCS, Santos CLA (1987a) Sobre a ocorrência de pegadas e pistas de dinossauros na localidade de Engenho Novo, Antenor Navarro, Paraíba (Grupo Rio do Peixe, Cretáceo Inferior). In: Congresso Brasileiro de Paleontologia, 10, Rio de Janeiro, anais, 2 vol., 1:353-366

Santos MFCS, Santos CLA (1987b) Novas pegadas de dinossauros retiradas de uma cerca de pedras no sítio Cabra Assada, Antenor Navarro, Paraíba (Grupo Rio do Peixe, Cretáceo Inferior). In: Congresso Brasileiro de Paleontologia, 10, Rio de Janeiro, anais, 2 vol., 1: 367-376

Siqueira LMP et al (2011) Sítios Paleontológicos das Bacias do Rio do Peixe: Georreferenciamento, Diagnóstico de Vulnerabilidade e Medidas de Proteção. Anuário do Instituto de Geociências-UFRJ 34(1):09-21

UNESCO (2014) World Geopark. http://www.worldgeopark.org. Accessed 10 June 2014 